\title{
FENOMENA GUGUR DAUN SEKUNDER DI WILAYAH SUMATERA UTARA DAN PENGARUHNYA TERHADAP PRODUKSI KARET
}

\author{
Secondary Leaf Fall Phenomena in North Sumateraand Its Impact to Rubber Yield \\ Junaidi, Radite Tistama, Atminingsih, Zaida Fairuzah,Arief Rachmawan, \\ Muhammad Rizqi Darojat, dan Mochlisin Andriyanto
}
Balai Penelitian Sungei Putih, Pusat Penelitian Karet , PO. Box. 1415 Medan 20001, Email: balitsp@indosat.net.id

Diterima 8 Februari 2018 / Direvisi 22 Maret 2018 / Disetujui 10 Juli 2018

\begin{abstract}
Abstrak
Fenomena gugur daun sekunder dialami kebun-kebun di wilayah Sumatera pada tahun 2017. Studi ini bertujuan untuk mengetahui penyebab fenomena gugur daun berulang serta dampaknya terhadap produksi. Data diperoleh melalui survei lapangan, pengamatan di laboratorium serta analisis data curah hujan dan produksi dari 35 blok pengamatan pada areal tanaman menghasilkan dari 20 kebun di wilayah Sumatera Utara yang dilaksanakan bulan September - Oktober 2017. Gugur daun sekunder sepanjang tahun 2017 disebabkan oleh serangan penyakit gugur daun yang dipicu oleh curah hujan yang tinggi pada bulan Maret 2017 karena pada periode ini tanaman sedang membentuk daun baru. Berdasarkan hasil pengamatan, Colletotrichum dan Fusicoccum merupakan penyakit yang dominan yang dijumpai, sedangkan Oidium ditemukan dalam skala kecil. Klon PB 260 merupakan klon yang paling banyak mengalami serangan. Serangan juga dijumpai pada klon PB 330, PB 340, RRIM 712, RRIM 911, dan RRIM 937. Penurunan produksi pada klon BPM 1 mencapai $14,0 \%$, sedangkan klon-klon lain secara berturut-turut adalah PB $330(14,4 \%)$, PB 340 (10,8\%), RRIM 712 (9,9\%), dan RRIM 937 (1,5\%). Pada klon PB 260 dan RRIM 911 tidak terjadi penurunan produksi. Berdasarkan jenis patogen yang menyerang, penurunan produksi sebesar 1,3\% dijumpai pada serangan Colletotrichum dan 2,7\% akibat Fusicoccum. Teknis pencegahan dan penanggulangan serangan penyakit gugur daun mendesak
\end{abstract}

untuk disosialisasikan kepada pekebun. Di samping itu, penelitian mengenai spesies dan ras baru patogen gugur daun perlu dilakukan terutama Fusicoccum mengingat penyakit ini tergolong baru di Indonesia dan belum banyak terpublikasi.

Kata kunci: Hevea brasiliensis, gugur daun, Colletotrichum, Fusicoccum, Oidium, curah hujan, produksi

\section{Abstract}

Secondary leaf fall phenomena was experienced by rubber plantations in North Sumatera in 2017. This study was aimed to perceive the cause of that phenomena and its impact to the yield. Data were collected through field survey, laboratory observation, and rainfall and yield data analysis from 35 observation blocks of mature plant from 20 estates in North Sumatera that were carried out in September-October 2017. The secondary leaf fall in 2017 was caused by leaf fall disease pathogens that was fathomed by the high intensity of the rainfall in March 2017 as plants were forming new leaves in this period. Observation results showed that Colletotrichum and Fusicoccum were found as dominant diseases, while Oidium was observed in less extent. Clone PB 260 was the most affected, while the diseases were also found in $P B$ 330, $P B$ 340, RRIM 712, RRIM 911, and RRIM 937. The yield declined $14.0 \%$ in clone BPM 1 , other clones were PB 330 (14,4\%), PB 340 (10,8\%), RRIM 712 (9.9\%) and RRIM 937 (1,5\%). Whilst in PB 260 and RRIM 911 did not showed a yield decline. Based on the pathogen, the yield declined up to $1.3 \%$ in 
Colletotrichum bout and 2.7\% in Fusicoccum.Prevention and mitigation of leaf fall disease were urgent to be socialized to the planters. Besides that, researches on new species and races of lead fall disease are noteworthy to be carried out especially Fusicoccum since it is quite new in Indonesia and still less publicized.

Keywords: Hevea brasiliensis, leaf fall, Colletotrichum, Fusicoccum, Oidium, rainfall, yield

\section{Pendahuluan}

Perubahan iklim global berdampak terhadap pertanian di daerah tropis termasuk Indonesia(Reilly, 1995; Rosegrant et al., 2008). Dampak terhadap tanaman perkebunan adalah penurunan produksi akibat perubahan pola curah hujan dan kejadian iklim ekstrim (Badan Penelitian dan Pengembangan Pertanian, 2011). Pada tanaman karet (Hevea brasiliensis Muell Arg.), penelitian Zhang et al. (2014) menunjukkan korelasi negatif antara curah hujan dengan hasil lateks. Curah hujan yang tinggi dapat mengganggu kegiatan penyadapan serta menurunkan kualitas lateks. Selain itu, curah hujan tinggi dapat memicu serangan penyakit gugur daun (Nurhayati \& Situmorang, 2008). Penyakit gugur daun Colletotrichum misalnya, serangan berat umumnya terjadi di wilayah dengan curah hujan di atas $3000 \mathrm{~mm} /$ tahun (Basuki, 1990). Hal ini dapat diperparah dengan komposisi tanaman yang tidak berimbang karena kecenderungan menggunakan klon-klon tertentu yang berpotensi dipatahkan oleh ras baru patogen penyakit gugur daun yang menyebabkan serangan penyakit menyebar dalam skala luas.

Produktivitas tanaman karet sangat erat kaitannya dengan kondisi tajuk (Rodrigo, 2007). Hal ini disebabkan bahan baku partikel karet adalah asimilat hasil fotosintesis (See Chow et al., 2012). Setiap tahunnya tanaman karet akan menggugurkan daunnya dan diganti dengan daun baru (Priyadarshan, 2011). Selama periode ini produksi karet mencapai titik terendah karena pasokan asimilat sangat minim dan adanya kompetisi penggunaan asilimilat dengan daun dan tunas yang baru tumbuh (Oktavia \& Lasminingsih, 2010). Pada periode ini pula terjadi peningkatan kandungan $\mathrm{N}, \mathrm{P}, \mathrm{K}$, dan $\mathrm{Mg}$ dalam lateks yang berpengaruh pada penurunan lama aliran lateks (Siregar, 2008). Letak geografis mempengaruhi periode gugur daun. Di wilayah utara khatulistiwa periode gugur daun jatuh pada semester pertama setiap tahun. Di Sumatera Utara misalnya, gugur daun terjadi di bulan Januari - Maret, pembentukan daun baru berlangsung Maret April. Di Selatan Khatulistiwa gugur daun terjadi pada semester kedua, contohnya di Jawa, gugur daun umumnya berlangsung Juni - Agustus, pada bulan September sudah terbentuk daun baru(Priyadarshan et al., 2001; Junaidi et al., 2015).

Periode pembentukan daun baru merupakan titik kritis yang menentukan potensi produksi tahun berikutnya (Junaidi \& Atminingsih, 2017). Jika tanaman gagal membentuk daun dalam periode tersebut, maka tajuk tanaman akan tipis sepanjang tahun sampai periode gugur daun berikutnya. Dalam kondisi normal gugur daun hanya terjadi sekali dalam setahun, namun di tahun 2017 ini banyak keluhan dari pekebun terkait fenomena gugur daun sekunder hampir menyeluruh di wilayah Sumatera Utara. Gugur daun sekunder yang dimaksud dalam artikel ini adalah kondisi dimana daun yang baru terbentuk gugur kembali, kemudian disusul munculnya tunas dan daun muda namun gugur kembali. Hal ini sangat merugikan karena tajuk menjadi tipis dan periode gugur daun menjadi panjang (Viswanathan et al., 2005). Kondisi ini mempengaruhi pasokan asimilat bahan baku biosintesis karet. Dari sisi teknis, tajuk yang tipis menghambat penggalian produksi di lapangan antara lain karena penundaan penggunaan dan penurunan respon stimulan yang berimplikasi pada produksi.

Fenomena gugur daun sekunder yang terjadi hampir di seluruh wilayah Sumatera Utara diduga merupakan dampak perubahan pola curah hujan pada tahun 2017 yang 
memicu meluasnya serangan penyakit gugur daun. Studi ini bertujuan mengetahui penyebab terjadinya gugur daun sekunder, jenis penyakit, serta dampaknya terhadap produksi karet. Hasil studi ini diharapkan dapat menjadi pertimbangan pekebun dalam pencegahan dan penanggulangan penyakit gugur daun pada tanaman karet.

\section{Bahan dan Metode}

Studi dilakukan pada bulan September Oktober 2017 terhadap 34 lokasi pengamatan yang merupakan blok tanaman karet menghasilkan di 20 kebun karet yang tersebar di 6 Kabupaten (Deli Serdang, Serdang Bedagai, Simalungun, Asahan, Labuhan Batu dan Tapanuli Selatan di Provinsi Sumatera Utara (Tabel 1). Blok-blok pengamatan ditentukan dari informasi pihak kebun kemudian ditindaklanjuti dengan kunjungan ke lapangan untuk pengamatan visual dan pengambilan sampel daun.

Blok-blok pengamatan terdiri dari klon $\mathrm{PB}$ 260, PB 330, PB 340, RRIM 712, RRIM 911, RRIM 937, IRR 104, RRIM 901, RRIM 912, RRIM 931, dan BPM 1 (Tabel 2). Klon-klon tersebut merupakan klon yang dominan ditanam di kebun-kebun yang diamati. Selain klon-klon tersebut juga ditanam klon-klon lain dalam jumlah yang lebih sedikit.

Pengamatan dilakukan di areal tanaman menghasilkan dengan umur bervariasi antara 5 tahun sampai 16 tahun (Tabel 3). Sistem sadap yang diterapkan di lokasi pengamatan bervariasi sesuai sistem sadap tipologi klon berdasarkan rekomendasi Balai Penelitian Sungei Putih.

Tabel1. Lokasi kebun yang menjadi areal pengamatan

\begin{tabular}{ll}
\hline \multicolumn{1}{c}{ Wilayah } & \multicolumn{1}{c}{ Kebun } \\
\hline Deli Serdang dan Sedang Bedagai & Sei Putih, Sarang Giting, Rambutan \\
& Tanah Raja, Silau Dunia \\
Simalungun & Gunung Para, Gunung Pamela, Bangun, Bandar \\
Asahan & Betsy \\
Labuhan Batu & Sei Silau, Ambalutu, Pulau Mandi, Dusun Hulu \\
Tapanuli Selatan & Membang Muda, Labuhan Haji, Merbau Selatan, \\
\hline
\end{tabular}

Tabel 2. Jumlah blok pengamatan berdasarkan klon dan umur tanaman

\begin{tabular}{lccc}
\hline & Klon & $\begin{array}{c}\text { Jumlah blok } \\
\text { pengamatan }\end{array}$ & $\%$ \\
\hline PB 260 & 13 & 38.24 \\
PB 330 & 4 & 11.76 \\
PB 340 & 6 & 17.65 \\
RRIM 712 & 2 & 5.88 \\
RRIM 911 & 2 & 5.88 \\
RRIM 937 & 2 & 5.88 \\
IRR 104 & 1 & 2.94 \\
RRIM 901 & 1 & 2.94 \\
RRIM 912 & & 1 & 2.94 \\
RRIM 931 & & 1 & 2.94 \\
BPM 1 & Jumlah & 1 & 2.94 \\
& & 34 & 100.00 \\
\hline
\end{tabular}


Tabel 3. Jumlah blok pengamatan berdasarkan klon dan umur tanaman

\begin{tabular}{ccc}
\hline Umur & $\begin{array}{c}\text { Jumlah titik } \\
\text { pengamatan }\end{array}$ & $\%$ \\
\hline 16 & 1 & 2.94 \\
13 & 2 & 5.88 \\
12 & 3 & 8.82 \\
11 & 4 & 11.76 \\
10 & 2 & 5.88 \\
9 & 6 & 17.65 \\
8 & 2 & 5.88 \\
7 & 2 & 5.88 \\
6 & 9 & 26.47 \\
5 & 3 & 8.82 \\
Jumlah & 34 & 100.00 \\
\hline
\end{tabular}

Data curah hujan diperoleh dari pengukuran masing-masing kebun meliputi curah hujan selama periode Januari - Agustus 2017 serta curah hujan tahun 2013 - 2016. Untuk mengetahui besarnya penyimpangan (deviasi) curah hujan tahun 2017 terhadap tahun-tahun sebelumnya, persentase selisih curah hujan bulanan tahun 2017 terhadap ratarata curah hujan empat tahun sebelumnya (2013 - 2016) pada bulan yang sama dengan persamaan berikut:

$$
\begin{array}{ll}
D= & \frac{(\mathrm{Cht}-\mathrm{CHa})}{(\mathrm{CHa})} \times 100 \% \\
D & : \text { Deviasi }(\%) \\
\mathrm{CH} t & : \text { Curah hujan tahun } 2017(\mathrm{~mm}) \\
\mathrm{CHa} & : \text { Rata-rata curah hujan tahun } 2013 \\
& -2016(\mathrm{~mm})
\end{array}
$$

Contoh daun yang terkena penyakit diamati di Laboratorium Proteksi Tanaman, Balai Penelitian Sungei Putih. Spora patogen dibiakkan dalam media Potato Dextrose Agar (PDA) dan diamati di bawah mikroskop untuk mengetahui jenis patogen yang menyerang secara pasti. Data produksi dari areal yang mengalami gugur daun berulang diperoleh dari produksi bulanan (Januari - September) dalam berat kering per hektar (kg/ha). Perbandingan terhadap produksi dilakukan pada areal-areal yang mengalami serangan dengan mempertimbangkan posisi panel serta sistem sadap yang sama dengan tahun sebelumnya. Persentase produksi pada tahun 2017 dihitung dengan persamaan berikut:

$$
\begin{array}{ll}
P P= & \frac{(P t-P a)}{P a} \times 100 \% \\
P P & : \text { Persentase produksi }(\%) \\
P t & : \text { Produksi tahun } 2017(\mathrm{~kg} / \mathrm{ha}) \\
P a & : \text { Produksi tahun } 2016(\mathrm{~kg} / \mathrm{ha})
\end{array}
$$

\section{Hasil dan Pembahasan}

\section{Pola curah hujan dan kaitannya dengan gugur daun berulang}

Intensitas dan pola curah hujan mempengaruhi tingkat serangan penyakit gugur daun pada tanaman karet. Nurhayati \& Situmorang (2008) menyimpulkan bahwa epidemi penyakit gugur daun disebabkan pergeseran pola pembentukan daun muda dan pergeseran curah hujan. Jika terjadi hujan berselang-seling dengan hari panas selama periode pembentukan daun baru, maka kemungkinan muncul epidemi semakin besar. Periode gugur daun di wilayah Sumatera Utara umumnya terjadi antara bulan Februari - April (Siregar, 2014). Pada tahun 2017, secara umum, curah hujan pada periode tersebut cukup tinggi (Gambar 1). Periode kritis pembentukan daun baru adalah pada bulan Maret karena daun muda baru muncul dan rentan terserang patogen gugur daun. Pada bulan ini curah hujan di wilayah Deli Serdang 
dan Serdang Bedagai adalah 138,4 mm, Simalungun 239,3 mm, Asahan 115,0 mm, Labuhan Batu $314,8 \mathrm{~mm}$, dan Tapanuli Selatan 241,1 mm. Rata-rata curah hujan di wilayah Sumatera Utara menunjukkan pola umum tinggi pada awal tahun kemudian menurun pada Februari - Maret, selanjutnya sedikit meningkat pada bulan April - Mei dan menurun lagi pada Juni - Juli, peningkatan tajam terjadi mulai bulan Agustus sampai akhir tahun. Pada tahun 2017, curah hujan tergolong tingi dari bulan Januari - Mei. Secara spesifik, curah hujan bulan Januari dan Maret lebih tinggi dibanding lima tahun sebelumnya pada bulan yang sama.

Menurut Tjasyono (2004), iklim di Indonesia secara umum dapat dibagi dalam tiga pola berdasarkan sebaran curah hujan

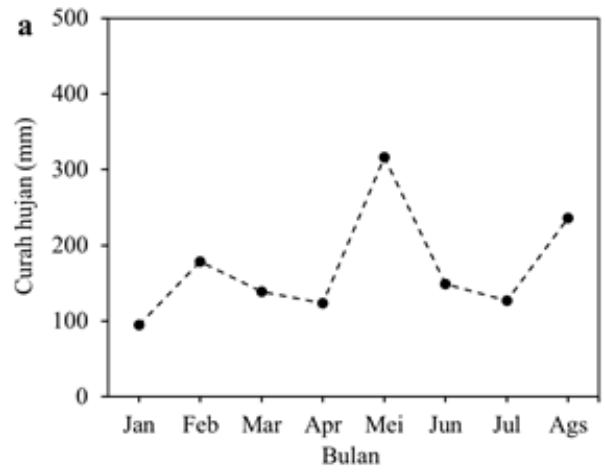

tahunan yaitu pola monsunal, ekuatorial, dan lokal. - Aldrian \& Susanto (2003) mengelompokkan wilayah Sumatera Utara ke dalam wilayah curah hujan pola ekuatorial yang dicirikan dengan dua puncak hujan (bimodial), biasanya terjadi sekitar bulan Maret dan Oktober atau pada saat terjadi ekinoks. Curah hujan lima tahun terakhir menunjukkan pola umum dengan dua puncak curah hujan masih konsisten, namun pada tahun 2017 terjadi penyimpangan (deviasi) cukup tinggi pada bulan Januari $(77,4 \%)$ dan Maret (181,0\%) (Gambar 2), sedangkan bulanbulan lainnya cenderung mendekati rata-rata curah hujan empat tahun sebelumnya, bahkan curah hujan bulan Juni dan Juli mengalami deviasi negatif masing-masing sebesar $4,0 \%$ dan $14,9 \%$.

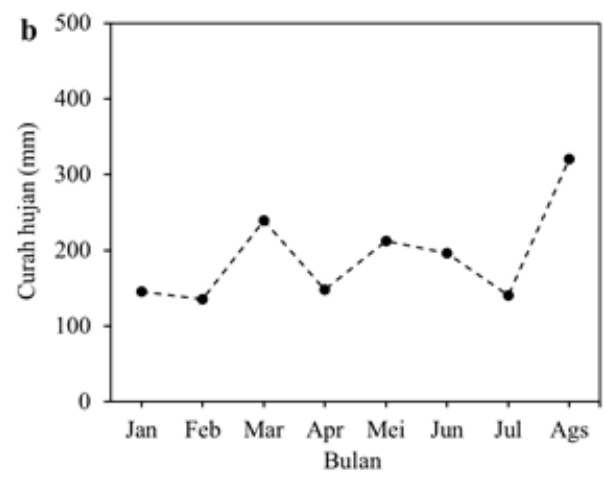


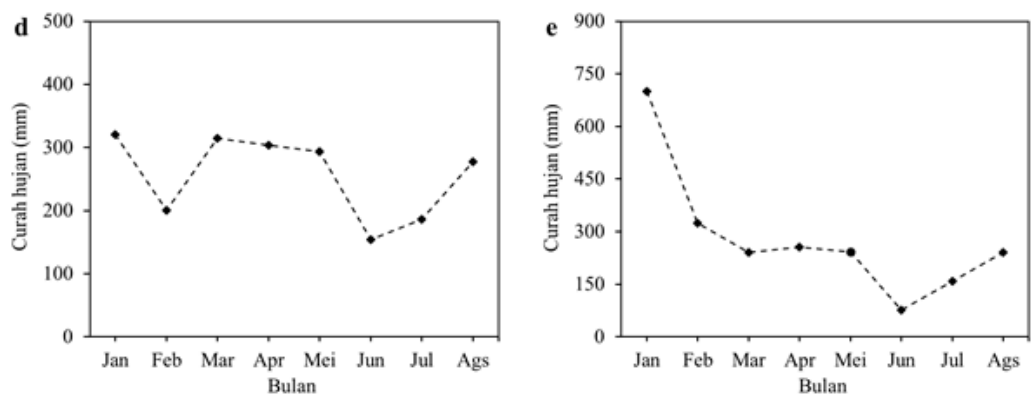

Gambar 1. Rata-rata curah hujan tahun 2017 di wilayah Deli Serdang dan Serdang Bedagai (a), Simalungun (b), Asahan (c), Labuhan Batu (d), dan Tapanuli Selatan (e) 


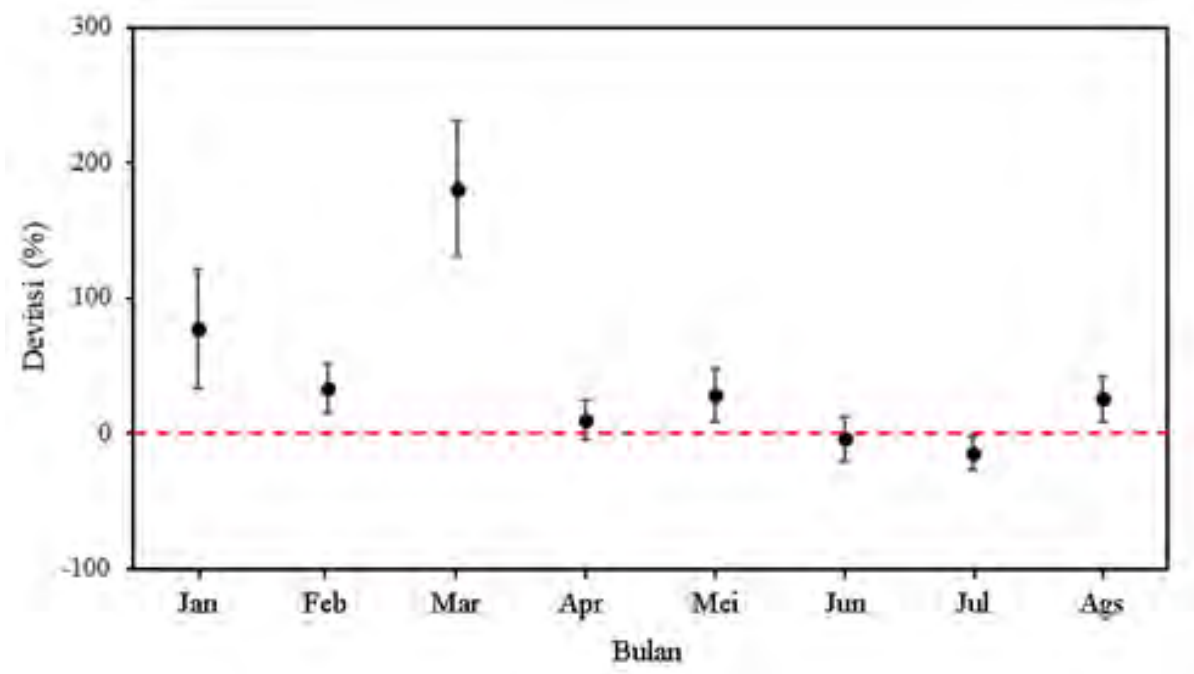

Gambar2. Deviasi curah hujan tahun 2017 terhadap rata-rata curah hujan empat tahun sebelumnya. Errorbarmenunjukkan 95\% selang kepercayaan.

Deviasi yang sangat tinggi pada bulan Maret menjawab hipotesis hasil penelitian bahwa curah hujan pada periode pembentukan daun baru memicu serangan penyakit gugur daun. Gugur daun berikutnya disebabkan peningkatan curah hujan pada bulan Mei (deviasi 19,9\%) ketika tunas dan daun baru muncul kembali. Webster \& Paardekooper (1989) menyatakan jika kondisi lingkungan lembab karena curah hujan yang tinggi pada periode pembentukan daun baru, penyakit gugur daun akan menyerang daun muda yang baru terbentuk sehingga menimbulkan gugur daun sekunder. Hasil penelitian sesuai dengan Wastie (1972) yang melakukan studi di wilayah semenanjung Malaya, hasilnya menunjukkan bahwa curah hujan dan hari hujan pada bulan Maret (bulan pembentukan daun baru) merupakan faktor paling penting yang memicu gugur daun abnormal. Faktor lain dengan efek lebih kecil antara lain suhu, kelembaban, dan lama penyinaran. Penelitian lainnya yang dilakukan oleh Rosenzweig et al. (2001) menyimpulkan bahwa distribusi spasial dan temporal serta laju peningkatan serangan patogen dipengaruhi unsur-unsur iklim karena suhu, cahaya, dan kelembaban adalah faktor yang mengontrol pertumbuhan dan perkembangan patogen.

\section{Jenis penyakit gugur daun yang dijumpai}

Pengamatan yang dilakukan pada bulan September-Oktober 2017 menunjukkan bahwa Colletrotichum merupakan jenis penyakit dominan yang dijumpai di wilayah Sumatera Utara pada tahun 2017. Dari 34 blok yang diamati, Colletotrichum ditemukan di 23 lokasi pengamatan $(68 \%)$ terdiri dari serangan tunggal di 17 lokasi serta bersamaan dengan Oidium (1 lokasi) dan Fusicoccum (5 lokasi). Fusicoccum, patogen yang tergolong baru, dalam studi ini dijumpai di 15 lokasi (44\%) terdiri dari serangan tunggal di 10 lokasi dan 5 lokasi bersamaan dengan Colletotrichum. Penyakit Oidium hanya dijumpai di dua lokasi masing-masing satu lokasi merupakan serangan tunggal dan lainnya bersamaan dengan Colletotrichum (Tabel 4). Fusicoccum merupakan penyakit dominan di wilayah Deli Serdang dan Serdang Bedagai (42,9\%) serta Simalungun (77,8\%). Informasi mengenai patogen ini belum banyak diteliti sehingga kondisi lingkungan yang menyebabkan perkembangan dan penyebaran patogen ini secara luas belum diketahui. Serangan gugur daun di wilayah Asahan dan Labuhan Batu didominasi oleh Colletotrichum masing-masing sebesar $87,5 \%$ dan $80,0 \%$ blok pengamatan. 
Fenomena gugur daun sekunder di wilayah Sumatera Utara dan pengaruhnya terhadap produksi karet

Tabel 4. Persentase blok terserang pada masing-masing wilayah pengamatan

\begin{tabular}{lcccccccccc}
\hline \multirow{1}{*}{ Jenis Serangan } & $\begin{array}{c}\text { D. Serdang dan } \\
\text { S. Bedagai } \\
(\mathrm{n}=7)\end{array}$ & $\begin{array}{c}\text { Simalungun } \\
(\mathrm{n}=9)\end{array}$ & $\begin{array}{c}\text { Asahan } \\
(\mathrm{n}=8)\end{array}$ & $\begin{array}{c}\text { Labuhan Batu } \\
(\mathrm{n}=10)\end{array}$ & $\begin{array}{c}\text { Total } \\
(\mathrm{n}=34)\end{array}$ \\
\cline { 2 - 11 } & $\begin{array}{c}\text { Jumlah } \\
\text { blok }\end{array}$ & $\begin{array}{c}\text { Jumlah } \\
\text { blok }\end{array}$ & $\%$ & $\begin{array}{c}\text { Jumlah } \\
\text { blok }\end{array}$ & $\%$ & $\begin{array}{c}\text { Jumlah } \\
\text { blok }\end{array}$ & $\%$ & $\begin{array}{c}\text { Jumlah } \\
\text { blok }\end{array}$ & $\%$ \\
\hline Colletotrichum & 2 & 28,6 & - & - & 7 & 87,5 & 8 & 80,0 & 17 & 50,0 \\
Oidium & 1 & 14,3 & - & - & - & - & - & & 1 & 2,9 \\
Fusicoccum & 3 & 42,9 & 7 & 77,8 & - & - & - & & 10 & 29,4 \\
Colletotrichum + Oidium & - & - & - & - & - & - & 1 & 10,0 & 1 & 2,9 \\
Colletotrichum + Fusicoccum & 1 & 14,3 & 2 & 22,2 & 1 & 12,5 & 1 & 10,0 & 5 & 14,7 \\
Oidium + Fusicoccum & - & - & - & - & - & - & - & - & - & - \\
\hline
\end{tabular}

Catatan: D. Serdang = Deli Serdang

S. Bedagai = Serdang Bedagai

Patogen ini umumnya menyerang daun-daun muda yang baru terbentuk. Curah hujan yang tinggi pada periode pembentukan daun baru merupakan salah satu faktornya.

Penyakit hawar daun Fusicoccum ditandai dengan gejala hawar yang berubah dari terang menjadi coklat tua. Gejala khas pada daun yang lebih tua adalah munculnya batas dan area kecoklatan yang konsentris dengan konidia pada permukaan atas daun (Gambar 3a). Daun yang terinfeksi berat akan mengering dan gugur atau bertahan tapi dalam bentuk yang tidak normal (Ngobisa et al., 2012). Konidia patogen Fusicoccum pada perbesaran 40 x 10 di bawah mikroskop disajikan pada Gambar 3b. Ngobisa et al. (2013) menggambarkan bahwa konidia Fusicoccum berbentuk elips dengan ujung bundar berukuran 16,5-24,0 x 3,5-6,5 m.
Serangan patogen ini di Indonesia masih belum banyak dipublikasikan namun perlu diantisipasi penyebarannya sejak dini mengingat dampak serangannya cukup signifikan.

Karakteristik serangan Colletotrichum secara visual adalah kerutan pada tepi dan ujung daun. Selain itu, pada permukaan daun terdapat bercak-bercak berbentuk bulat berwarna coklat dengan tepi kuning, bergaris tengah 1-2 $\mathrm{mm}$ (Gambar 4a). Bila daun bertambah umurnya, bercak akan berlubang di tengahnya, dan bercak tampak menonjol dari permukaan daun yang merupakan ciri khas penyakit ini - (Semangun, 2000). Konidia patogen Colletotrichum pada perbesaran $40 \times 10$ di bawah mikroskop disajikan pada Gambar 4b. Senaratna et al. (1991) mengamati karakter morfologis dua isolat patogen Colletotrichum
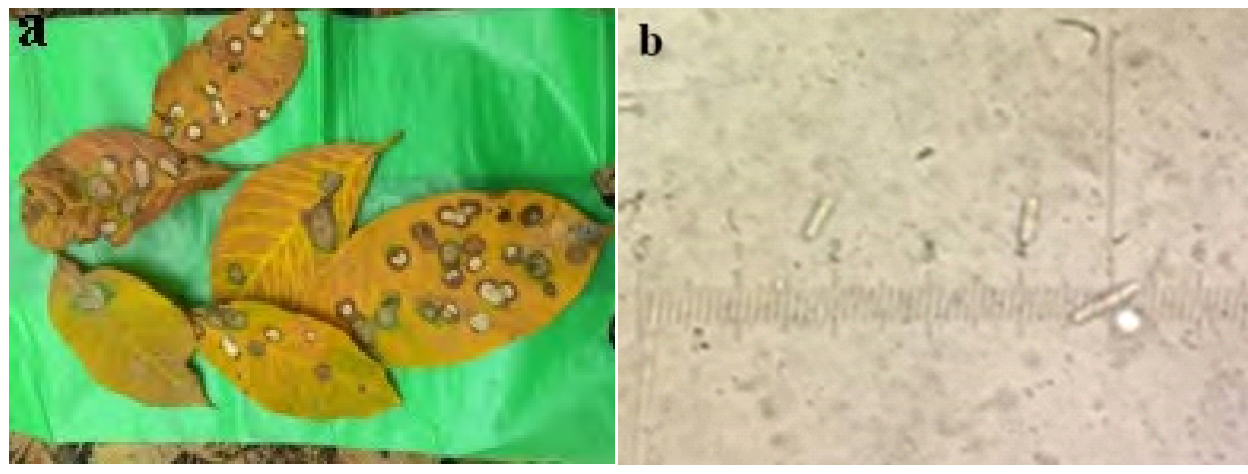

Gambar 3. Gejala serangan penyakit Fusicoccum (a) dan konidia patogen Fusicoccum di bawah mikroskop pada perbesaran $40 \times 10$ (b) 


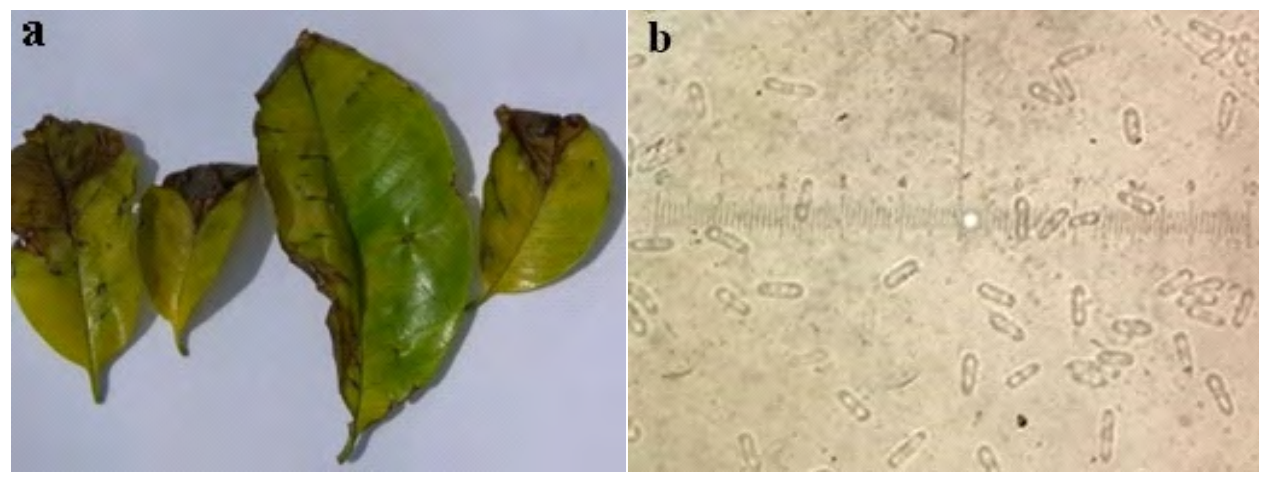

Gambar 4. Gejala serangan penyakit Colletotrichum (a) dan konidia patogen Colletotrichum di bawah mikroskop pada perbesaran 40 x 10 (b)

gloeosporioides dan menyimpulkan bahwa kedua isolat tampak mirip kecuali warna konidia berwarna pink salmon dengan ukuran panjang $11 \times 73 \pm 1 \times 79$ m dan berwarna hialin dengan panjang konidia $14 \times 71 \pm 2 \times 13$ m.

Penyakit embun tepung Oidium ditandai dengan terbentuknya area bertepung putih yang tipis di atas permukaan lembaran daun (Gambar 5a). Serangan berat pada daun yang sangat muda menyebabkan lembaran daun menjadi keriput, layu, mengering, dan gugur. Serangan berulang dapat menyebabkan perlambatan pertumbuhan dan penurunan produksi (International Rubber Research and Development Board, 2006). Konidia Oidium heveae pada perbesaran 40 x 10 di bawah mikroskop disajikan pada Gambar 5b. - Limkaisang et al. (2005) menggambarkan fitur mikroskopis Oidium berupa konidia berukuran $25-44 \times 13-23 \mathrm{~m}$ dengan rasio panjang: lebar 1,4 - 2,5. Konidia primer berbentuk ellips dan membulat di bagian ujungnya sedangkan konidia sekunder berbentuk ellips sampai silinder, tanpa ujung yang membulat.

\section{Jenis Klon yang Mengalami Serangan Penyakit Gugur Daun}

Dari 23 blok pengamatan yang mengalami serangan Colletotrichum, semua areal klon RRIM $911(\mathrm{n}=2)$, RRIM $937(\mathrm{n}=2)$, dan PB $340(\mathrm{n}=4)$ terkena serangan Colletotrichum. Klon lain yang terserang adalah PB 260 $(61,5 \% ; n=8), \quad$ PB $340(50,0 \% ; n=3)$, sedangkan kumulatif klon-klon lain sebesar $57,1 \%(n=4)$. Serangan Fusicoccum dijumpai di 15 blok pengamatan. Semua blok klon RRIM $712(\mathrm{n}=2)$ mengalami serangan Fusicoccum.

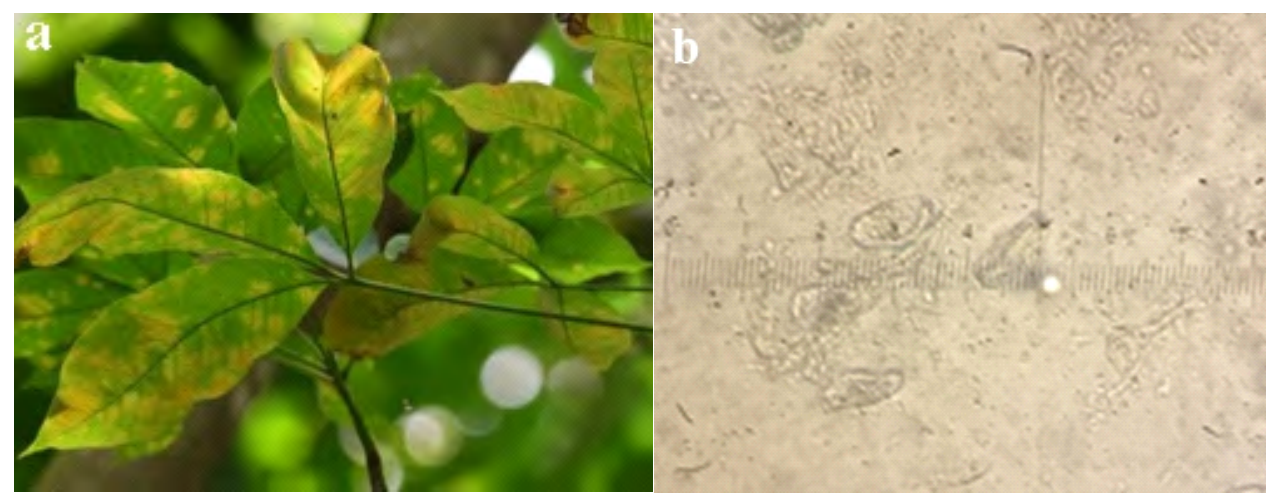

Gambar 5. Gejala serangan penyakit Oidium (a) dan konidia patogen Oidium di bawah mikroskop pada perbesaran $40 \times 10$ (b) 
Klon lain yang terserang adalah PB 260 $(46,2 \% ; \mathrm{n}=6)$, PB $340(66,7 \% ; \mathrm{n}=4)$, sedangkan kumulatif klon-klon lainnya mencapai 14,3\% ( $=3$ ) (Tabel 5). Klon PB 260 merupakan klon yang paling banyak dibudidayakan di wilayah Sumatera Utara (Tabel 6). Dalam penelitian ini, areal-areal klon PB 260 banyak mengalami serangan penyakit gugur daun. Hal ini berbeda dengan Situmorang et al. (2005) yang menyatakan bahwa PB 260 adalah salah satu klon yang banyak dibudidayakan di tingkat petani dan perusahaan perkebunan yang memiliki resistansi cukup baik terhadap penyakit gugur daun selain BPM 1dan RRIC 100. Penelitian Daslin (2013) menunjukkan bahwa klon PB 260 sebenarnya moderat resisten terhadap Colletrotichum dan Oidium. Ngobisa et al. (2015) juga menyimpulkan PB 260 sebagai klon moderat resisten terhadap Fusicoccum. Klonklon introduksi seperti RRIM 911 dan RRIM 937 mengalami serangan diduga karena keduanya berasal dari induk yang sama dengan PB 260 yaitu PB 5/51 (Othman et al., 1996).

Data yang dikumpulkan menunjukkan klon-klon unggul yg selama ini dikenal cukup toleran terhadap penyakit gugur daun mengalami serangan hampir di semua lokasi pengamatan. Di samping disebabkan penanamannya secara luas, kemungkinan munculnya ras-ras baru patogen gugur daun yang mematahkan resistensi klon perlu diselidiki. Perakitan klon-klon unggul baru harus mempertimbangkan aspek evolusi patogen ini sehingga dapat menghasilkan klon yang toleran. Penelitian ini juga menunjukkan pentingnya keseimbangan komposisi klon dalam sudut pandang pencegahan penyebaran penyakit.

\section{Pengaruh terhadap Produksi}

Serangan penyakit gugur daun dapat menurunkan produksi secara signifikan. Sebagai contoh, serangan hawar daun Amerika Selatan (South American Leaf Blight) yang disebabkan cendawan Microcyclus ulei dilaporkan dapat menurunkan produksi hingga $10-30 \%$ (Situmorang et al., 2008), sedangkan Corynespora cassicola menurunkan produksi hingga 30 - 40\% (Pawirosoemardjo, 2006; Soepena et al., 1996). Pada tanaman yang mengalami gugur daun abnormal akibat Phytophthora spp, produksi turun $7-32 \%$ (Jacob et al., 2006).

Dalam studi ini, penurunan produksi pada areal-areal yang terserang Colletotrichum sebesar 1,3\% dan Fusicoccum sebesar 2,7\% (Gambar 6), sedangkan pada serangan Oidium tidak dijumpai penurunan produksi. Penurunan produksi ini jauh di bawah hasil

Tabel 5. Persentase titik serangan Colletotrichum dan Fusicoccum

\begin{tabular}{lccr}
\hline \multicolumn{1}{c}{ Klon } & $\begin{array}{c}\text { Jumlah } \\
\text { titik sampel }\end{array}$ & $\begin{array}{c}\text { Jumlah } \\
\text { titik serangan }\end{array}$ & $\%$ \\
\hline Colletotrichum & & & \\
RRIM 911 & 2 & 2 & 100,0 \\
PB 260 & 13 & 2 & 61,5 \\
RRIM 937 & 2 & 4 & 100,0 \\
PB 330 & 4 & 3 & 100,0 \\
PB 340 & 6 & 4 & 50,0 \\
Lainnya & 7 & 23 & 57,1 \\
Jumlah & 34 & 2 & 67,7 \\
Fusicoccum & 2 & 6 & 100,0 \\
RRIM 712 & 13 & 4 & 46,2 \\
PB 260 & 6 & 3 & 66,7 \\
PB 340 & 21 & 15 & 14,3 \\
Lainnya & 34 & & 44,1 \\
Jumlah & & & \\
\hline
\end{tabular}


Tabel 6. Komposisi klon areal tanaman menghasilkan pada tahun 2016 dari seluruh kebun

\begin{tabular}{lcc}
\hline Klon & $\begin{array}{c}\text { Luas } \\
(\text { ha })\end{array}$ & $\begin{array}{c}\text { Persentase } \\
(\%)\end{array}$ \\
\hline PB 260 & $10.583,31$ & 43,7 \\
PB 340 & $4.516,07$ & 18,6 \\
PB 330 & $2.508,40$ & 10,4 \\
RRIM 911 & $1.304,40$ & 5,4 \\
RRIM 921 & $1.059,11$ & 4,4 \\
RRIM 937 & $1.033,98$ & 4,3 \\
BPM 24 & 669,37 & 2,8 \\
RRIM 901 & 567,30 & 2,3 \\
Poliklon & 393,18 & 1,6 \\
RRIC 100 & 337,19 & 1,4 \\
RRIM 931 & 318,10 & 1,3 \\
BPM 1 & 290,24 & 1,2 \\
Lainnya & 637,44 & 2,6 \\
Total & $24.218,09$ & 100,0 \\
\hline
\end{tabular}

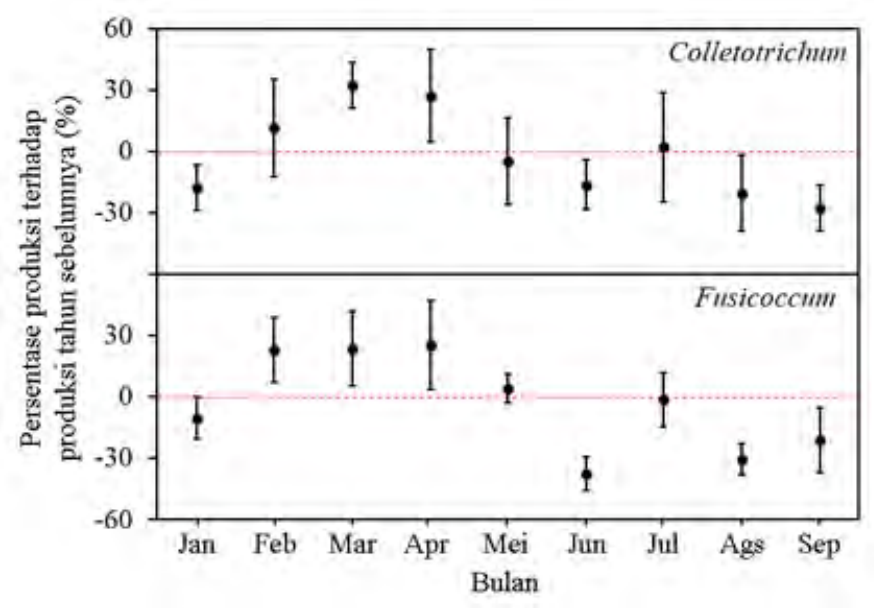

Gambar6. Persentase produksi tahun 2017 terhadap produksi tahun 2016 berdasarkan jenis serangan penyakit gugur daun. Error barmenunjukkan 95\% selang kepercayaan.

pengamatan Ogbebor et al. (2007) pada serangan Colletotrichum yang mencapai $7-45 \%$ dan Priyadarshan et al. (2005) yang melaporkan penurunan $14-29 \%$ pada serangan Oidium. Hal ini kemungkinan disebabkan tingkat serangan yang sporadis dan tidak seberat yang dilaporkan pada kedua artikel tersebut. Meskipun dari sisi penurunan produksi tergolong kecil, pencegahan dan pengendalian penyakit gugur daun harus dilakukan. Jika gugur daun terjadi terusmenerus dalam beberapa siklus perdaunan, maka kesehatan tanaman akan menurun karena jumlah daun yang tidak memadai untuk menghasilkan fotosintat. Jika hal ini terjadi, maka penurunan produksi akan semakin besar. 
Penurunan produksi pada klon BPM 1 mencapai $14.0 \%$, sedangkan klon-klon lain secara berturut-turut adalah PB $330(14,4 \%)$, PB 340 (10,8\%), RRIM 712 (9,9\%), dan RRIM 937 (1,5\%) (Gambar 7). Pada klon PB 260 dan RRIM 911 tidak terjadi penurunan produksi. Klon PB 260 diketahui memiliki tajuk yang efisien terlihat dari kebiasaan meluruhkan percabangan bawah yang tidak mendapat sinar matahari langsung (Hoong, 1997), serta memiliki pola percabangan ringan berimbang (Rubber Board, 2018). Dalam kondisi perubahan iklim global saat ini, selain klonklon yang resisten terhadap ras baru patogen, klon-klon yang memiliki efisiensi penggunaan sinar matahari diyakini akan memberi manfaat yang signifikan.

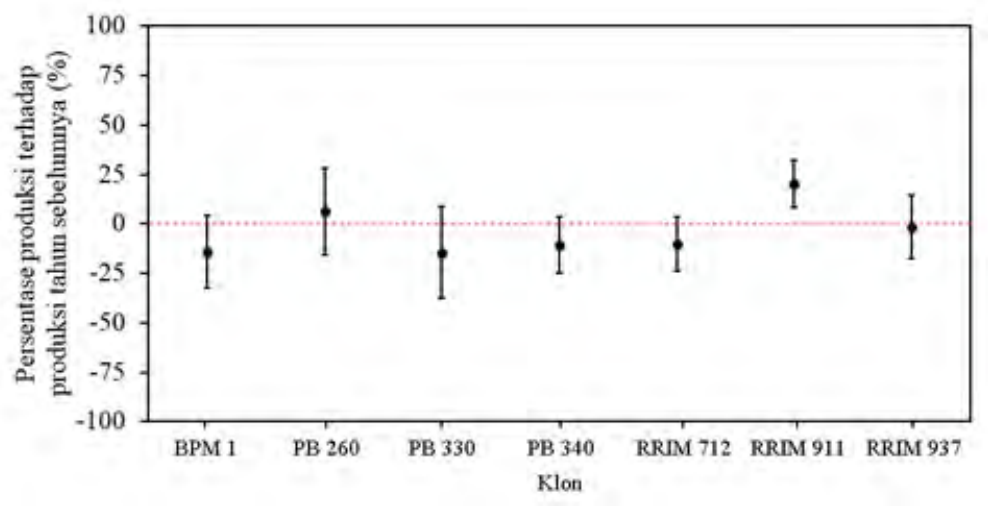

Gambar 7. Persentase produksi tahun 2017 terhadap produksi tahun 2016 berdasarkan jenisklon. Errorbarmenunjukkan $95 \%$ selang kepercayaan.

\section{Upaya Pencegahan dan Penanggulangan Penyebaran Penyakit Gugur Daun}

Pengendalian penyakit gugur daun untuk mengembalikan kondisi tajuk akan meningkatkan produksi. Peningkatan 50\% kerapatan tajuk melalui pengendalian penyakit Colletotrichum pada klon GT 1 dapat meningkatkan produksi sampai 40\% (Guyot et al., 2001). Pengendalian kuratif dengan fungisida adalah hal umum di perkebunan karet. Namun demikian, pengendalian dengan metode ini memiliki kendala dari biaya maupun teknis pelaksanaan, sehingga saat ini banyak petani dan perusahaan perkebunan yang tidak lagi melakukan penyemprotan fungisida untuk mengendalikan penyakit gugur daun di areal tanaman menghasilkan.

Dalam jangka panjang, Situmorang et al. (2005) menekankan pentingnya mempertimbangkan penggunaan klon-klon resisten di wilayah-wilayah endemik penyakit gugur daun. Misalnya, untuk mencegah penyebaran Colletotrichum, penggunaan klonklon yang resisten dianjurkan untuk daerah dengan ketingggian $>300 \mathrm{~m}$ di atas permukaan laut dengan curah hujan yang tinggi (tipe A), sedangkan klon-klon yang resisten terhadap Oidium disarankan ditanam di daerah yang sering terjadi hujan rintik pada periode pembentukan daun baru, kondisi ideal untuk perkembangan patogen Oidium.

Pusat Penelitian Karet sejak lama memberikan perhatian penuh dalam upaya perakitan klon-klon yang resisten terhadap penyakit gugur daun. Dalam setiap seri klon IRR yang diseleksi terdapat beberapa klon yang telah teruji resisten terhadap patogenpatogen umum. Klon IRR 100 dan IRR 104 diketahui memiliki ketahanan yang baik terhadap Colletrotichum dan Oidium(Woelan et al., 2005; Dalimunthe et al., 2015). Klon-klon 
IRR seri 200 yang resisten terhadap penyakit Corynespora danColletotrichum adalah IRR 220 dan IRR 230 (Woelan et al., 2016; Woelan et al., 2005). -Daslin et al. (2012) menambahkan IRR 207, IRR 208, dan IRR 211 ke dalam kelompok klon yang resisten. Klon IRR seri 300 yang resisten terhadap Colletotrichum adalah IRR 300, IRR 301, IRR 302, IRR 304, IRR 307, IRR 308, IRR 309, IRR 313, IRR 314, IRR 315, IRR 316, IRR 317, IRR 318, IRR 319, dan IRR 321 (Woelan et al., 2009). Pengamatan yang dilakukan oleh Pasaribu et al. (2015) berhasil mendeteksi enam klon IRR seri 400 yang resisten terhadap serangan Colletotrichum yaitu IRR 428, IRR 429, IRR 446, IRR 451 dan IRR 452.

Karakteristik tanaman karet yang memiliki siklus ekonomi panjang (25-30 tahun) menuntut upaya pencegahan penyebaran penyakit didesain sejak awal. Situmorang et al. (2005) mengusulkan beberapa strategi pencegahan penyebaran penyakit gugur daun yang dapat diterapkan antara lain:

1. Membatasi penanaman klon yang telah ditanam dalam skala luas

Membatasi penanaman klon-klon seperti PB 260, PB 340, dan PB 330 yang sudah dominan di kebun-kebun yang diamati. Klon RRIM seri 900 seperti RRIM 911, RRIM 921, dan RRIM 937 juga mulai mendominasi, proporsinya akan terus meningkat seiring gencarnya penanaman klon-klon tersebut di areal tanaman belum menghasilkan (TBM). Penggunaan klonklon unggul baru yang telah teridentifikasi memiliki resistensi tinggi sangat dianjurkan sebagai alternatif pengganti klon-klon yang telah banyak ditanam.

2. Penanaman banyak klon secara berimbang

Menggunakan banyak jenis klon dengan proporsi genetik resistensi yang berimbang.

Dianjurkan untuk menanam sedikitnya enam klon dalam satu hamparan tanaman. Setiap klon ditanam dalam satu blok namun klon-klon yang resistensinya sama diupayakan tidak saling berdekatan.
3. Penanaman klon campuran (mixed clones)

Beberapa klon dengan proporsi genetika resistensi tertentu ditanam merata dalam satu blok. Metode ini sangat efektif mencegah penyebaran penyakit gugur daun, namun secara agronomis tidak menguntungkan karena menimbulkan pertumbuhan tidak seragam sehingga matang sadap tidak serempak. Selain itu, metode ini akan menyulitkan penerapan sistem sadap berdasarkan tipologi klon.

4. Penempatan klon pada lokasi tertentu (Zoning environmax)

Metode ini menempatkan klon tertentu pada satu wilayah yang telah teridentifikasi jenis dan karakteristik serangan penyakit gugur daunnya. Untuk itu diperlukan informasi jenis penyakit, data iklim/cuaca, dan klon-klon yang sesuai untuk agroklimat tersebut. Di Indonesia, strategi ini belum diterapkan secara luas karena keterbatasan informasi-informasi yang dibutuhkan.

Selain strategi-strategi tersebut di atas, gugur daun buatan (artificial defoliation) juga dapat dilakukan untuk pencegahan penyakit gugur daun. Pendekatan ekstrim ini memaksa tanaman menggugurkan daunnya dan membentuk daun pada bulan yang diinginkan agar terhindar dari kondisi iklim yang sesuai untuk perkembangan penyakit gugr daun. Dalam prakteknya, penyemprotan etilen dalam jumlah besar dilakukan untuk memicu gugur daun (Rao, 1972). Pendekatan ini sulit dilakukan karena memerlukan sumber daya yang besar namun dapat menjadi alternatif untuk dipertimbangkan.

\section{Kesimpulan}

Curah hujan yang tinggi di bulan Maret diduga memicu serangan penyakit gugur daun karena pada periode tersebut tanaman sedang membentuk daun baru. Peningkatan curah hujan pada bulan Mei menyebabkan daun baru gugur kembali. Areal yang mengalami 
serangan diprediksi mengalami tajuk tipis sepanjang tahun. Colletotrichum dan Fusicoccum sangat dominan dijumpai sedangkan Oidium dijumpai dalam skala kecil. Klon yang banyak mengalami gugur daun adalah klon-klon dominan seperti PB 260, PB 330, PB 340, RRIM 712, RRIM 911, dan RRIM 937. Penurunan produksi di areal yang terinfeksi patogen mencapai $1,3 \%$ akibat serangan Colletotrichum dan 2,7\% akibat Fusicoccum. Disarankan untuk melakukan penelitian lanjutan untuk mendapatkan persentase penurunan produksi yang lebih akurat. Selain penanggulangan kuratif melalui penyemprotan pestisida, strategi jangka panjang untuk meminimalisir penyakit gugur daun dapat dilakukan dengan adopsi klonklon unggul yang resisten dan mendesain komposisi klon dengan proporsi genetik resistensi yang berimbang. Studi mengenai patogen Fusicoccum dinilai mendesak untuk dilakukan mengingat penyakit ini tergolong baru menyerang tanaman karet di Indonesia dan informasi terkait patogen ini belum banyak diketahui.

\section{Ucapan Terima Kasih}

Ucapan terima kasih disampaikan kepada PT. Perkebunan Nusantara III (Persero) atas ijin lokasi pengamatan dan bantuan yang diberikan selama kegiatan pengamatan berlangsung.

\section{Daftar Pustaka}

Aldrian, E., \& Susanto, R. D. (2003). Identification of three dominant rainfall regions within Indonesia and their relationship to sea surface temperature. International Journal of Climatology, 23(12), 1435-1452. doi:10.1002/joc.950

Badan Penelitian dan Pengembangan Pertanian. (2011). Pedoman Umum Adaptasi Perubahan Iklim Sektor Pertanian. Jakarta, Indonesia: Badan Penelitian dan Pengembangan Pertanian, Kementerian Pertanian Republik Indonesia.
Basuki. (1990). Penyakit gugur daun colletotrichum pada tanaman karet. Buletin Pusat Penelitian Perkebunan Tanjung Morawa, 1(2), 3-17.

Dalimunthe, C., Fairuzah, Z., \& Daslin, A. (2015). Ketahanan lapangan tanaman karet klon IRR seri 100 terhadap tiga patogen penting penyakit gugur daun. Jurnal Penelitian Karet, 33(1), 35-46.

Daslin, A. (2013). Ketahanan genetik berbagai klon karet introduksi terhadap penyakit gugur daun. Jurnal Penelitian Karet, 31(2), 79-87. Retrieved from http://ejournal. puslitkaret.co.id/index.php/jpk/article/vi ew/135

Daslin, A., Woelan, S., \& Pasaribu, S. A. (2012). High latex yielding and disease resistance of rubber clones IRR 200 series. Indonesian Journal of Agricultural Science, 13(2), 80-85. doi:10.21082/ijas.v13n2. 2012.p80-85

Guyot, J., Omanda, E. N., Ndoutoume, A., Otsaghe, A. M., Enjalric, F., \& Assoumou, H. G. N. (2001). Efect of controlling Colletotrichum leaf fall of rubber tree on epidemic development and rubber production. Crop Protection, 20(7), 581-590. doi:10.1016/S0261-2194(01)00027-8

Hoong, C. W. (1997). Performance of clone PB 260 in a large plantation group in Peninsular Malaysia. The Planter, 73(857), 403-418.

International Rubber Research and Development Board. (2006). Portrait of the Global Rubber Industry. Kuala Lumpur, Malaysia: International Rubber Research and Development Board.

Jacob, C. K., Prern, E. E., Manju, M. J., ldicula, S. P., \& Edathil, T. T. (2006). Crop loss due to abnormal leaf fall disease of rubber (Hevea brasiliensis) caused by Phytophthora spp. Natural Rubber Research, 19(1 \& 2), 1-8. Retrieved from http:// rubberboard.org.in/publications/NRvol19 .pdf 
Junaidi, \& Atminingsih. (2017). Perkembangan ontogenetik daun tanaman karet sebagai penanda awal adaptasi terhadap cekaman lingkungan dan patogen. Warta Perkaretan, 36(1), 29-38. Retrieved from http://ejournal.puslitkaret. co.id/index.php/wartaperkaretan/article/ view/296/pdf_1

Junaidi, Sembiring, Y. R. V., \& Siregar, T. H. S. (2015). Pengaruh perbedaan letak geografi terhadap pola produksi tahunan tanaman karet: Faktor penyebab perbedaan pola produksi tahunan tanaman karet. Warta Perkaretan, 34(2), 137-146. doi:10.22302 /ppk.wp.v34i2.254

Limkaisang, S., Kom-un, S., Fertado, E. L., Liew, K. W., Salleh, Y. S., \& Takamatsu, S. (2005). Molecular phylogenetic and morphological analysis of $\mathrm{O}$. heveae, a powdery mildew of rubber tree. Mycoscience, 46, 220-226. doi:10.1007/s10267-0050238-8

Ngobisa, A. I. C. N., Abidin, M. A. Z., Wong, M. Y., \& Murnita, M. M. (2012). Cultural and morphological characterisations of Fusicoccum sp., the causal agent of rubber (Hevea brasiliensis) leaf blight in Malaysia. Journal of Rubber Research, 15(1), 64-79. Retrieved from http://rios.lgm.gov.my /cms/fedDigiJournalDetail.jsp?searchTex $\mathrm{t}=\&$ selTa $\mathrm{b}=$ digiCon\&id=\&type $=J R R \&$ iss ueYear $=2012$

Ngobisa, A. I. C. N., Abidin, M. A. Z., Wong, M. Y., Nasehi, A., Godswill, N. N., \& Ndongo Pierre-Andre, O. N. (2015). Susceptibility of rubber (Hevea brasiliensis) clones to Neofusicoccum ribis. World Journal of Agricultural Research, 3(6), 198-202. doi:10.12691/wjar-3-6-3

Ngobisa, A. I. C. N., Abidin, M. A. Z., Wong, M. Y., \& Wan Noordin, M. W. D. (2013). Neofusicoccum ribis associated with leaf blight on rubber (Hevea brasiliensis) in Peninsular Malaysia. The Plant Pathology Journal, 29(1), 10-16. doi:10.5423/ PPJ.OA.07.2012.0110
Nurhayati, \& Situmorang, A. (2008). Pengaruh pola hari hujan terhadap perkembangan penyakit gugur daun Corynespora pada tanaman karet menghasilkan. Jurnal Hama dan Penyakit Tumbuhan Tropika, 8(1), 63-70. Retrieved from http://jhpttropika.fp.unila.ac.id /index.php/jhpttropika/article/view/265

Ogbebor, N. O., Adekunle, A. T., \& Enobakhare, D. A. (2007). Inhibition of Colletotrichum gloeosporioides (Penz) Sac. causal organism of rubber (Hevea brasiliensis Muell. Arg.) leaf spot using plant extracts. African Journal of Biotechnology, 6(3), 213-218. doi:10.5897 /AJB06.145

Oktavia, F., \& Lasminingsih, M. (2010). Pengaruh kondisi daun tanaman karet terhadap keragaman hasil sadap beberapa klon IRR. Jurnal Penelitian Karet, 28(2), 3240.

Othman, R., Benong, M., Ong, S. H., \& Hashim, I. (1996, 16-17 Desember). Strategies and development of resistant Hevea clones againts Corynespora leaf fall. Tulisan disajikan pada Workshop on Corynespora Leaf Fall Disease, Medan.

Pasaribu, S. A., Rosmayati, \& Sumarmadji. (2015). Uji ketahanan klon karet IRR seri 400 terhadap beberapa isolat penyakit gugur daun Colletotrichum. Jurnal Penelitian Karet, 33(2), 131-142. Retrieved from http://ejournal.puslitkaret. co.id/index.php/jpk/article/view/178

Pawirosoemardjo, S. (2006, 4-6 September). Manajemen pengendalian penyakit pada tanaman karet. Tulisan disajikan pada Lokakarya Nasional Budidaya Tanaman Karet 2006, Medan.

Priyadarshan, P. M. (2011). Biology of Hevea Rubber. Preston, UK: CAB International.

Priyadarshan, P. M., Hoa, T. T. T., Huasun, H., \& de-Goncalves, P. S. (2005). Yielding potential of rubber (Hevea brasiliensis) in sub-optimal environments. Journal of Crop Improvement, 14, 221-247. doi:10.1300 /J411v14n01_10 
Priyadarshan, P. M., Sasikumar, S., \& Goncalves, P. D. S. (2001). Phenological change in Hevea brasiliensis under differential geo-climates. The Planter, 77(905), 447-459.

Rao, B. S. (1972). Chemical defoliation of Hevea brasiliensis for avoiding secondary leaf fall. Journal Rubber Research Institute of Malaya, 23(3), 248-256.

Reilly, J. (1995). Climate change and agriculture: Recent findings and issues. American Journal of Agricultural Economics, 77(3), 727-733.

Rodrigo, V. H. L. (2007). Ecophysiological factors underpinning productivity of Hevea brasiliensis. Brazilian Journal of Plant Physiology, 19(4), 245-255. doi:10.1590 /S1677-04202007000400002

Rosegrant, M. W., Ewing, M., Yohe, G., Burton, I., Huq, S., \& Valmonte-Santos, R. (2008). Climate Change and Agriculture: Threats and Opportunities. Eschborn, Germany: Deutsche Gesellschaft für, Technische Zusammenarbeit (GTZ) $\mathrm{GmbH}$.

Rosenzweig, C., Iglesius, A., Yang, X. B., Epstein, P. R., \& Chivian, E. (2001). Climate change and extreme weather events: Implications for food production, plant diseases, and pests. Global Change and Human Health, 2(2), 90-104. doi:10.1023 /A:1015086831467

Rubber Board. (2018). PB 260. Kerala, India: Rubber Board, Ministry of Commerce and Industry, Goverment of India.

See Chow, K. S., Mat-Isa, A. B., A , Ghazali, A. K., Alias, H., Zainuddin, Z. M., Hoh, C. C., \& Wan, K. L. (2012). Metabolic routes affecting rubber biosynthesis in Hevea brasiliensis latex. Journal of Experimental Botany, 63(5), 1863-1871. doi:10.1093 $/ \mathrm{jxb} / \mathrm{err} 363$

Semangun, H. (2000). Penyakit - penyakit tanaman perkebunan di Indonesia. Yogyakarta, Indonesia: Gadjah Mada University Press.
Senaratna, L. K., Wijesundera, R. L. C., \& Liyanage, A. S. (1991). Morphological and physiological characters of two isolates of Colletotrichum gloeosporioides from rubber (Hevea brasiliensis). Mycological Research, 95(9), 1085-1089. doi:10.1016 /S0953-7562(09)80552-2

Siregar, T. H. S. (2008). Dinamika Kerontokan Daun Pohon Karet (Hevea brasiliensis Muell. Arg.) dan Hasil Lateks. (Doktor Disertasi), Universitas Gadjah Mada, Yogyakarta.

Siregar, T. H. S. (2014). Pola musiman produksi dan gugur daun pada klon PB 260 dan RRIC 100. Jurnal Penelitian Karet, 32(2), 88-97. Retrieved from http://ejournal. puslitkaret.co.id/index.php/jpk/article/vi ew/155

Situmorang, A., Lasminingsih, M., \& Wijaya, T. (2005, 22-23 November). Resistensi klon karet anjuran dan strategi penggunaannya dalam pengendalian penyakit penting di perkebunan karet Indonesia. Tulisan disajikan pada Lokakarya Nasional Pemuliaan Tanaman Karet 2005, Medan.

Situmorang, A., Suryaningtyas, H., \& Febbiyanti, T. R. (2008, 20-21 Agustus). Penyakit hawar daun Amerika Selatan dan pengendaliaanya pada tanaman karet. Tulisan disajikan pada Lokakarya Nasional Agribisnis Karet 2008, Yogyakarta.

Soepena, H., Suwarto, \& Sinulingga, W. (1996, 16 - 17 September 1996). Chemical control of Corynespora leaf fall. Tulisan disajikan pada Workshop on Corynespora Leaf Fall Disease, Medan.

Tjasyono, B. (2004). Klimatologi Umum. Bandung, Indonesia: Institut Teknologi Bandung.

Viswanathan, P. K., Kadavil, T. G., \& Jacob, C. K. (2005). Crop loss in rubber due to abnormal leaf fall: an analysis on the economic feasibility of plant protection measures in India. Journal of Plant Protection Research, 45(4), 235-248. 
Wastie, R. L. (1972). Factors affecting secondary leaf fall of Hevea in Malaysia. Journal of Rubber Research Institute of Malaya, 23(3), 232-247. Retrieved from https://journals.indexcopernicus.com/sea $\mathrm{rch} /$ article? articleId $=161810$

Webster, C. C., \& Paardekooper, E. C. (1989). The botany of rubber tree. In C. C. a. W. J. B. Webster (Ed.), Rubber (pp. 57-84). London, UK: Longman Scientific and Technical.

Woelan, S., Azwar, R., Daslin, A., Suhendry, I., Lasminingsih, M., Sayurandi, \& Pasaribu, S. A. (2016). Keunggulan klon karet IRR 220 dan IRR 230. Warta Perkaretan, 35(2), 89-106. Retrieved from http://dx.doi.org/10.22302/ppk.wp.v35i2 .238

Woelan, S., Dasli, A., Suhendry, I., \& Lasminingsih, M. (2005, 22-23 November). Evaluasi keragaan klon karet IRR seri 100 dan 200. Tulisan disajikan pada Lokakarya Nasional Pemuliaan Tanaman Karet 2005, Medan.
Woelan, S., Daslin, A., Lasminingsih, M., \& Suhendry, I. (2009, 4-6 Agustus). Evaluasi keragaan klon karet IRR 200 dan 300 pada tahap pengujian. Tulisan disajikan pada Lokakarya Nasional Pemuliaan Tanaman Karet 2009, Batam.

Zhang, H., Zhang, L., Ge, Y., Hua, Y., Lan, Z., \& Huang, H. (2014). Climate and Latex Production of Rubber Tree (Hevea Brasiliensis Muell. Arg.) in Wanning, Southeastern Part of Hainan Province, China. Journal of Rubber Research, 17(4), 261-265. Retrieved from http:// rios.lgm.gov.my/cms/journalChildDetails .jsp?childKey $=$ vital1 $\% 5$ C: $86995 \&$ title $=$ Jo urnal\%20of\%20Rubber\%20Research 